\title{
THE ROLE OF WORK MOTIVATION IN MEDIATING THE EFFECT OF THE WORK ENVIRONMENT ON EMPLOYEE PERFORMANCE
}

\author{
Muhammad Andi Prayogi ${ }^{1}$, Irma Yani ${ }^{2}$ \\ ${ }^{1.2}$ Faculty of Economics and Business, Universitas Muhammadiyah Sumatera Utara \\ E-mail: muhammadandi@umsu.ac.id
}

\begin{abstract}
This study aims to determine the effect of the work environment on employee performance mediated by work motivation at the Dinas Pemuda dan Olahraga of North Sumatra province. The method used in this research is using a quantitative descriptive approach. The population in this study were general employees in the youth and sports department of the province of North Sumatra with a total population of 107 and in this study the sample obtained was 52 respondents. The results of this study indicate that the work environment has a positive but not significant effect on. employee performance, work environment has a positive and significant effect on work motivation, work motivation has a positive and insignificant effect on employee performance, work environment on employee performance is mediated by work motivation.
\end{abstract}

Keywords: work environment, work motivation and employee performance

\section{INTRODUCTION}

At this time the level of competition among companies is increasing rapidly. Every company must have reliable human resources in facing the dynamics of competition that exists at this time. Employees are an important asset owned by a company, therefore they must be maintained and developed so that the goals of a company can be realized properly. Reliable human resources must be able to manage the activities of the organization and its operational functions properly, such as planning, organizing, directing and supervising. The person who supervises the existing human resources is the general manager who is in a company organization (Bangun, 2012). Employee performance is the result of work achievement which is assessed in terms of quality based on existing work standards within the organization or within the work agency (Hasibuan, 2013). Performance is a condition that must be known about the level of achievement of individual results associated with the vision originating in an organization, as well as knowing the positive and negative impacts of an operational policy. The performance of an employee towards the company is often very important in the world of work. Every company wants its employees to have good performance at work in order to create good performance among employees, it takes a good work environment from the company and good work motivation from employees (Amy, 2013). The performance of an employee towards the company is often very important in the world of work. Every company wants its employees to have good performance at work in order to create good performance among employees, it takes a good work environment from the company and good work motivation from employees (Amy, 2013). The performance of an employee towards the company is often very important in the world of work. Every company wants its employees to have 


\section{Volumes 1 No 2 (2021)}

\section{The Role of Work Motivation in Mediating the Effect of the Work Environment on Employee Performance \\ DOI: 10.54443/ijebas.v1i2.75}

good performance at work in order to create good performance among employees, it takes a good work environment from the company and good work motivation from employees (Amy, 2013).

Performance is the result of work achieved by a person based on job requirements (Bangun, 2012). A job has certain requirements to be carried out in achieving goals which are also known as job standards. If the employee's performance is good, the company will get the goals of what the company expects with the performance results that the employee provides. Performance is a benchmark for employees in carrying out tasks that are targeted to complete and efforts to conduct performance appraisals are important by knowing the right performance measurement (Subroto, 2017). according to (Timpe and Harun, 2018)there are three factors that affect employee performance, namely: 1) skill level, 2) level of effort, 3) external conditions. The measuring tools of a performance are: a) quality of work, b) quantity of work, c) punctuality, d) effectiveness, and e) independence (Robbin, 2015).

The work environment in a company is very important to be considered by management even though the work environment does not carry out the production process in a company, but the work environment has a direct influence on the employees who carry out the production process. On the other hand, an inadequate work environment will cause a decrease in employee performance and a decrease in work motivation. The work environment is everything that is around employees that can affect employees in carrying out the tasks assigned by the company (Siagian and Khair, 2018). The work environment in a company needs to be considered, in this case because the work environment can affect employee morale (Jufrizen and Ramadhani, 2020). The measuring tools of a work environment are: An employee is not only required to work well so that the company' s goals are achieved, but an employee must also be motivated by his superiors to be able to work well, carefully and full of responsibility for his work. Motivation is an activity that causes a person to complete his work with enthusiasm, willing and full of responsibility (Fachrezi \& Khair, 2020). Motivation serves as a driving force or encouragement for employees to want to work diligently for the achievement of agency goals properly. Motivation is an urge to act on a series of processes of human behavior by considering the direction, intensity, and persistence in achieving goals. Work motivation affects employee performance, because with high motivation, employees will be encouraged to work well to produce maximum performance (Surwanti, 2011). The motivation of people depends on the strength of their motives. Motives are sometimes define as needs, wants, or impulses within the individual (Kadarisma, 2012). In essence, the purpose of providing work motivation to employees is to: 1) Change employee behavior in accordance with the wishes of the company, 2) Increase passion and morale, 3) Improve work discipline, 4) Improve work performance, 5) Increase sense of responsibility, 6) Increase sense of responsibility, 7) Increase productivity and efficiency, and 8) Grow employee loyalty to the company (Saydam, 2012). The measuring tools of a motivation are: a) Hard work, b) Orientation and future, c) High level of ideals, d) Task or target orientation, e) Efforts to advance, f) Perseverance, g) Coworkers who selected for the experts, and h) Time utilization (Mangkunegara, 2013). Providing motivation to employees is expected to be able to provide more effective performance results for the company. Effectiveness of employee performance is very important because it relates to the survival of the company in order to achieve company goals, the effectiveness of employee performance is one factor that needs to be considered. 


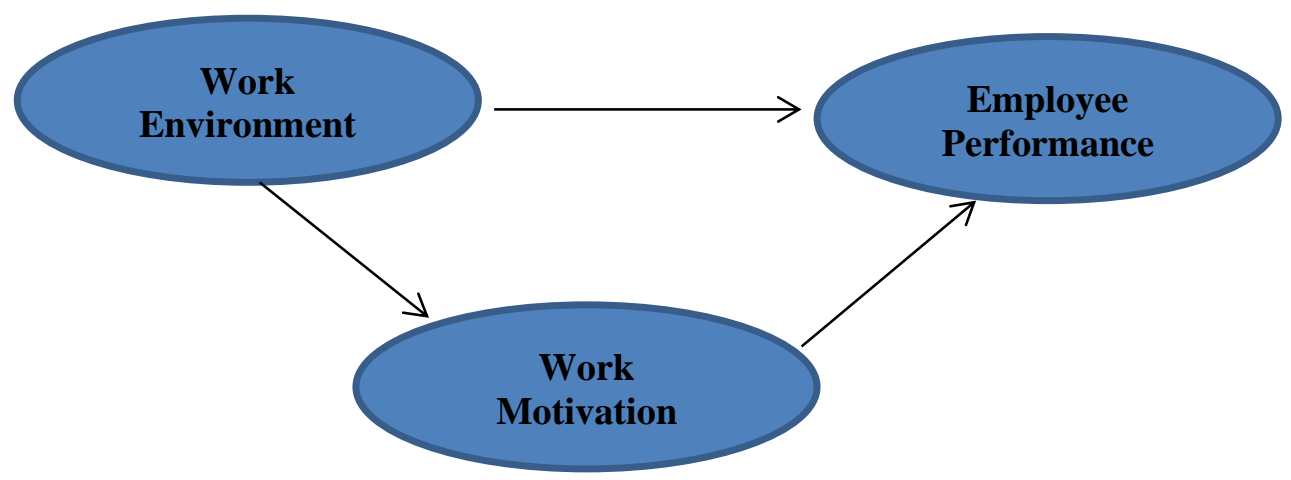

Figure 1. Research Paradigm

\section{RESEARCH METHOD}

This study uses an associative approach to determine the relationship between each variable, where the independent variable is the work environment $(\mathrm{X})$, the dependent variable is employee performance (Y), mediated by work motivation $(\mathrm{Z})$. Associative research isresearch that aims to determine the relationship between two or more variables (Sugiyono, 2016). The population in this study amounted to 107 permanent employees, where the sampling technique of this study used probability sampling using the slovin formula which can be obtained by the number of samples of 52 employees. The data collection technique is by distributing questionnaires, while the technique for analyzing data is by using SEM-PLS.SEM-PLS is a second generation multivariate analysis technique that combines factor and pathway analysis, making it possible for researchers to simultaneously test and estimate the relationship between multiple exogenous and endogenous multiple indicators. Partial Least Square (PLS) can be used to solve this problem. Partial Least Square (PLS), using two evaluation measurement models in the analysis test, namely a) Outer Model aims to test validity and reliability; b) Inner Model aims to test the quality (hypothesis testing to test the prediction model) (Haryono, 2016).

\section{RESULTS AND DISCUSSION}

\subsection{Coefficient of Determination ( $R$-square)}

$\mathrm{R}$-square is a measure of the proportion of variation in the value that is influenced (endogenous) which can be explained by the variables that influence it (exogenous). This is useful for predicting whether the model is good/bad. The r-square results for endogenous latent variables, namely: 1) If the value of $\mathrm{R} 2=0.75$, then the model is substance (strong), 2) If the value of $\mathrm{R} 2=$ 0.50 , then the model is moderate, 3 ) If value of $\mathrm{R} 2=0.25$, then the model is weak (bad).

Table 3.1.1. R-Square

\begin{tabular}{|l|c|c|}
\hline & R Square & $\begin{array}{c}\text { Adjusted R } \\
\text { Square }\end{array}$ \\
\hline Employee Performance (Y) & 0.152 & 0.118 \\
\hline Work Motivation $(\mathrm{Z})$ & 0.358 & 0.345 \\
\hline
\end{tabular}

Source: SmartPLS 3.0 Data Processing Results (2021) 
The Role of Work Motivation in Mediating the Effect of the Work Environment on Employee Performance

DOI: $10.54443 /$ ijebas.v1i2.75

Based on the table above, the results of the R-Square values that can be explained are: 1) R-Square adjusted $=0.118$, meaning that the ability of the work environment variable (X1) in explaining the employee performance variable ( $\mathrm{Y}$ ) is $11.8 \%$ indicating the model is weak (bad), 2) R-Square adjusted $=0.345$, meaning that the ability of the work environment variable (X1) in explaining the work motivation variable $(\mathrm{Z})$ is $34.5 \%$ indicating the model is weak (poor).

\subsection{F-Square}

Table 3.2.1 . F-Square

\begin{tabular}{|l|r|r|}
\hline & $\begin{array}{l}|l| \\
(\mathrm{Y})\end{array}$ & Work Motivation (Z) \\
\hline Work Environment (X) & 0.023 & 0.558 \\
\hline Employee Performance (Y) & 0.052 & \\
\hline Work Motivation (Z) & 0.052 & \\
\hline
\end{tabular}

Source: SmartPLS 3.0 Data Processing Results (2021)

Based on the table above, the results of the F-Square value can be explained, namely: 1) The F-Square value of the work environment variable $(\mathrm{X})$ on employee performance $(\mathrm{Y})$ is 0.023 , then the effect is moderate (moderate), 2) F value - The square of the work environment variable $(\mathrm{X})$ on work motivation $(\mathrm{Z})$ is 0.558 , then the effect is large (strong), 3) The F-Square value of the work motivation variable on employee performance $(\mathrm{Y})$ is 0.052 , so the effect is small (weak)

\subsection{Composite Reliability}

Construct reliability and validity can also be known through other methods, namely by looking at the composite reliability value. An indicator is declared to meet the requirements if the composite reliability value is > 0.6 (Aktarina, 2015)

Table 3.3.1 Composite Reability

\begin{tabular}{|c|c|}
\hline Variable & Composite Reliability \\
\hline Work Environment (X) & 0.945 \\
\hline Employee & 0.944 \\
\hline Performance (Y) & 0.941 \\
\hline Work Motivation (Z)
\end{tabular}

Source: SEM-PLS 3.0 data processing

The results from table 3.3.1 above, the results of the composite reliability values obtained in this study are as follows: 1) Based on the values obtained from the equation values above, it shows that the work environment variable $(\mathrm{X})$ is $0.945>0.6$, it can be concluded that the variable has good validity, 2) Based on the value obtained from the value of the equation above, it shows that the employee performance variable (Y) is 0.944 $>0.6$, it can be concluded that the variable has good validity, 3) Based on the value obtained from the value of the equation above, it shows that work motivation variable $(\mathrm{Z})$ is $0.941>0.6$, it can be concluded that the variable has good validity. 


\subsection{Cronbach's Alpha}

In addition to composite reliability, construct reliability and validity can also be determined by other methods, namely by looking at the value of Cronbach's alpha. An indicator is declared to meet the construct reliability and validity if the value of Cronbach's alpha > 0.7 (Aktarina, 2015).

Table 3.4.1 Cronbach's Alpha

\begin{tabular}{|l|c|}
\hline Variable & $\begin{array}{c}\text { Cronbach's } \\
\text { Alpha }\end{array}$ \\
\hline Work Environment $(\mathrm{X})$ & 0.936 \\
\hline Employee Performance $(\mathrm{Y})$ & 0.933 \\
\hline Work Motivation $(\mathrm{Z})$ & 0.931 \\
\hline
\end{tabular}

Source: SEM-PLS 3.0 . data processing

The results of the Cronbach's Alpha value in the table above, it can be concluded as follows: 1) Based on the results of the obtained equation values, it shows that the Cronbach alpha value of the work environment variable $(\mathrm{X})$ is $0.936>0.7$, it is known that the variable has good validity, 2) Based on the results of the equation values obtained, it shows that the cronbach alpha value of the employee performance variable $(\mathrm{Y})$ is $0.933>0.7$, it is known that the variable has good validity, 3) Based on the results of the equation value obtained, it shows that the cronbach alpha value of the work motivation variable $(\mathrm{Z})$ of $0.931>0.7$, it is known that the variable has good validity.

\subsection{Hypothesis test}

\subsubsection{Direct Effects}

The direct effect analysis is useful for testing the hypothesis of the direct effect of a variable that affects (exogenous) on the variable that is affected (endogenous). (Aktarina, 2015)with the criteria, namely: 1) if the path coefficient value is positive, then the effect of one variable on other variables is unidirectional. If the value of P-Values $<0.05$ then the results are significant, 2) if the path coefficient value is negative, then the influence of one variable on other variables is in the opposite direction. If the P-Values $>0.05$ then the results are not significant.

Table 3.5.1.1 Direct Effect

\begin{tabular}{|l|c|c|}
\hline & Original Sample (O) & P Values \\
\hline $\begin{array}{l}\text { Work Environment (X) -> Employee } \\
\text { Performance (Y) }\end{array}$ & 0.172 & 0.385 \\
\hline $\begin{array}{l}\text { Work Environment (X) -> Work } \\
\text { Motivation (Z) }\end{array}$ & 0.599 & 0.000 \\
\hline $\begin{array}{l}\text { Work Motivation (Z) -> Employee } \\
\text { Performance (Y) }\end{array}$ & 0.262 & 0.187 \\
\hline
\end{tabular}

Source: SmartPLS 3.0 Data Processing Results (2021) 
The Role of Work Motivation in Mediating the Effect of the Work Environment on Employee Performance

DOI: 10.54443/ijebas.v1i2.75

Based on the table above, the results of the Direct Effect values can be explained, namely: 1) The influence of the work environment $(\mathrm{X})$ on employee performance $(\mathrm{Y})$, the path coefficient has a value of 0.172 and $\mathrm{P}$ - values $0.385>0.05$, it is concluded that the results of the environmental influence work $(\mathrm{X})$ on employee performance $(\mathrm{Y})$ the results show positive and not significant, these results are in accordance with previous research conducted by (Hanafi \& Yohana, 2017) states that the work environment has a positive but not significant effect on employee performance, 2 ) the effect of the work environment $(X)$ on work motivation $(Z)$, the path coefficient has a value of 0.599 and P-values $0.000<0.05$, it is concluded that the effect of the work environment $(X)$ on work motivation (Z) the results show positive and significant, this is in accordance with what was studied by previous researchers (Sari \& Aziz, 2019)which states that the work environment has a positive and significant effect on work motivation. This shows that there is a direct influence of the work environment on work motivation, as evidenced by the magnitude of the influence of the work environment on work motivation, 3) The effect of work motivation (Z) on employee performance (Y), the path coefficient has a value of 0.262 and P-values $0.187>0.05$, it is concluded that the effect of work motivation $(\mathrm{Z})$ on employee performance $(\mathrm{Y})$ the results show positive and not significant, this is in accordance with what has been studied by (Islamiyah, 2019); (Murti \& Srimulyani, 2015); (Adha et al., 2019)where the results obtained are work motivation has a positive but not significant effect on employee performance. This shows that there is no significant effect.

\subsubsection{Indirect Effect}

The indirect effect is useful for testing the hypothesis of the indirect effect of an influencing variable (exogenous) on the influenced variable (endogenous) which is mediated by an intervening variable.(Juliandi, 2018). With the following criteria: a) If the P-Values $<0.05$, then the results are significant. This means that the mediator variable mediates the effect of exogenous variables on endogenous variables. In other words, the effect is not direct, b) If the P-Values > 0.05 , then the result is not significant. This means that the mediator variable does not mediate the effect of exogenous variables on endogenous variables. In other words, the effect is direct.

\section{Table 3.5.2.1 Indirect Effect}

\begin{tabular}{|l|c|c|}
\hline & & \\
& Original Sample (O) & P Values \\
\hline $\begin{array}{l}\text { Work Environment (X) -> Work Motivation (Z) -> } \\
\text { Employee Performance (Y) }\end{array}$ & 0.157 & 0.219 \\
\hline
\end{tabular}

Source: SmartPLS 3.0 Data Processing Results (2021)

Based on the data contained in the table above, the direct effect values observed in this study are: the influence of the work environment $(\mathrm{X})$ on employee performance $(\mathrm{Y})$ is mediated by work motivation (Z), the path coefficient has a value of 0.157 and P-values $0.219>0.05$, it can be concluded that the effect of the work environment $(\mathrm{X})$ on employee performance $(\mathrm{Y})$ is mediated by work motivation (Z). (Abdullah, 2021); (Islamiyah, 2019)where the results obtained are the work environment has a positive and significant effect on work motivation. This shows that there is 
a direct influence of the work environment on employee performance mediated by work motivation. This shows that there is no significant effect.

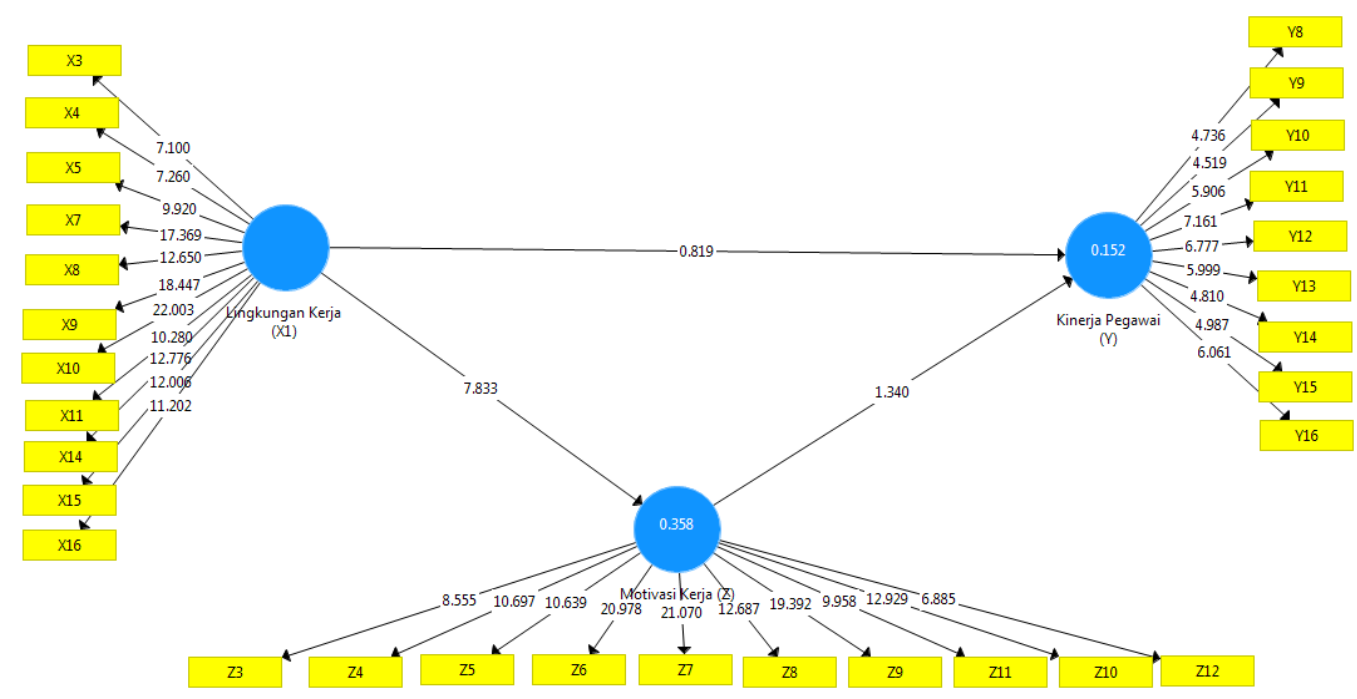

Figure 2. Results of the PLS Structural Model

\section{CONCLUSION}

The results of this study indicate that the work environment has a positive but not significant effect on employee performance, the work environment has a positive and significant effect on work motivation, work motivation has a positive and insignificant effect on employee performance, the work environment on employee performance is mediated by work motivation directly. there is a significant effect, while the work environment on employee performance is mediated by work motivation, the results are positive and not significant.

\section{REFERENCES}

AA. Anwar Prabu Mangkunegara. (2013). Manajemen Sumber Daya Manusia Perusahaan. Remaja Rosdakarya.

Abdullah, R. (2021). Pengaruh Stres Dan Lingkungan Kerja Terhadap Kinerja Yang Dimediasi Motivasi Kerja Karyawan Hotel Mm Ugm Yogyakarta. Journal of Tourism and Economic, 3(2), 126-134. https://doi.org/10.36594/jtec.v3i2.97

Adha, R. N., Qomariah, N., \& Hafidzi, A. H. (2019). Pengaruh Motivasi Kerja, Lingkungan Kerja, Budaya Kerja Terhadap Kinerja Karyawan Dinas Sosial Kabupaten Jember. Jurnal Penelitian IPTEKS, 4(1), 47. https://doi.org/10.32528/ipteks.v4i1.2109

Ainanur, A., \& Tirtayasa, S. (2018). Pengaruh Budaya Organisasi, Kompetensi dan Motivasi Terhadap Kinerja Karyawan. Jurnal Ilmiah Magister Manajemen, 1(1), 1-14.

Aktarina, D. (2015). Pengaruh Karakteristik Individu, Pekerjaan Dan Lingkungan Kerja Terhadap Motivasi Dan Dampaknya Terhadap Kinerja Anggota Polri Di Polresta Palembang. Jurnal Media Wahana Ekonomika, 12(3), 42-54.

Almustofa, R. (2014). Pengaruh Lingkungan Kerja, Motivasi Kerja, Disiplin Kerja Terhadap 


\section{Volumes 1 No 2 (2021)}

The Role of Work Motivation in Mediating the Effect of the Work Environment on Employee

Performance

DOI: $10.54443 /$ ijebas.v1i2.75

Kinerja Pegawai (Studi Pada Pegawai Perum Bulog Divisi Regional Jakarta). Fakultas Ekonomika dan Bisnis, Universitas Diponegoro.

Andayani, I., \& Tirtayasa, S. (2019). Pengaruh Kepemimpinan, Budaya Organisasi, Dan Motivasi Terhadap Kinerja Pegawai. Jurnal Ilmiah Magister Manajemen, 2(1), 45-54.

Andayani, I., \& Tirtayasa, S. (2019). The Influence of Leadership, Organizational Culture, and Motivation on Employee Performance. Maneggio: Jurnal Ilmiah Magister Manajemen, 2(1), 45-54.

Any, N. (2013). Manajemen Event. Alfabeta.

Arianty, N. (2015). pengaruh kepimpinan terhadap kinerja pegawai. Manajemen Toolsools, 5(2088-3145), 1.

Bahagia, R., Putri, L. P., \& Rizdwansyah, T. (2018). Pengaruh Kepemimpinan Dan Lingkungan

Kerja Terhadap Kinerja Karyawan Pada PT Pegadaian (PerseroKanwil I Medan. Prosiding Seminar Nasional Vokasi Indonesia, 1, 100-105.

Bangun, wilson. (2012). Manajemen Sumber Daya. Erlangga.

Bukhari, \& Pasaribu, S. E. (2019). Pengaruh Motivasi, Kompetensi, Dan Lingkungan Kerja Terhadap Kinerja. Jurnal Ilmiah Magister Manajemen, 2(1), 89-103.

Elizar, \& Tanjung, H. (2018). Pengaruh Pelatihan, Kompetensi, Lingkungan Kerja terhadap Kinerja Pegawai. Jurnal Ilmiah Magister Manajemen, 1(1), 46-58.

Erni, S., \& Donni, P. (2018). Kepemimpinan dan Perilaku Organisasi. Refika Aditama.

Fachrezi, H., \& Khair, H. (2020). Pengaruh Komunikasi, Motivasi dan Lingkungan Kerja Terhadap Kinerja Karyawan Pada PT. Angkasa Pura II (Persero) Kantor Cabang Kualanamu. Maneggio: Jurnal Ilmiah Magister Manajemen, 3(1), 107-119. https://doi.org/10.30596/maneggio.v3i1.4834

Farisi, S., \& Fani, W. M. (2019). Influence of Work Enviroment and Work Discipline on Employee Perfomance. International Conference on Global Education VII "Humanising Technology For IR 4.0," 69-81.

Farisi, S., \& Utari, R. U. (2020). Pengaruh Stres Kerja Dan Lingkungan Kerja Terhadap Kinerja Pegawai Dinas Kesehatan Provinsi Sumatera Utara. Jurnal Salman (Sosial Dan Manajemen), 1(1), 31-42.

Gultom, D. K., \& Arif, M. (2017). Kontribusi Nilai-Nilai Islam Terhadap Kinerja Pegawai Melalui Kepemimpinan: Studi Pada Pegawai Biro Universitas Islam Swasta Di Kota Medan. Jurnal Riset Sains Manajemen, 1(1), 67-78. https://doi.org/10.5281/zenodo.1048900

Hanafi, B. D., \& Yohana, C. (2017). Pengaruh Motivasi, Dan Lingkungan Kerja, Terhadap Kinerja Karyawan, Dengan Kepuasan Kerja Sebagai Variabel Mediasi Pada Pt Bni Lifeinsurance. Jurnal Pendidikan Ekonomi Dan Bisnis (JPEB), 5(1), 73-89. https://doi.org/10.21009/jpeb.005.1.6

Haryono. (2016). Siap Menghadapi Menstruasi dan Meopause. Gosyen Publishing.

Hasibuan, M. S. P. (2013). Sumber Daya Manusia. PT Bumi Aksara.

Hasibuan, S. M. (2018). Pengaruh Kepemimpinan, Lingkungan Kerja dan Motivasi Kerja Terhadap Kinerja. Jurnal Ilmiah Magister Manajemen, 1(1), 71-80.

Islamiyah. (2019). Pengaruh Lingkungan Kerja , Karakteristik Individu , Sebagai Variabel Intervening ( Studi Empiris Pada RSUD Muntilan Kabupaten Magelang ) SKRIPSI Untuk Memenuhi Sebagian Persyaratan Mencapai Derajat Sarjana S-1. 
Jakfar. (2013). Studi Kelayakan Bisnis Edisi Revisi.

Jufrizen, J. (2017). Pengaruh kemampuan dan motivasi terhadap kinerja perawat Studi pada Rumah Sakit Umum Madani Medan. Jurnal Riset Sains Manajemen, 1(1), 27-34. https://doi.org/10.5281/zenodo.1036809

Jufrizen, J. (2018). Peran Motivasi Kerja dalam Memoderasi Pengaruh Kompensasi dan Disiplin Kerja terhadap Kinerja Karyawan. Prosiding: The National Conferences Management and Business (NCMAB) 2018, 405-424.

Jufrizen, J., \& Hadi, F. P. (2021). Pengaruh Fasilitas Kerja dan Disiplin Kerja Terhadap Kinerja

Karyawan Melalui Motivasi Kerja. Jurnal Sains Manajemen, 7(1), 35-54. https://doi.org/10.30656/sm.v7i1.2277

Jufrizen, J., \& Pulungan, D. R. (2017). Implementation of Incentive and Career Development of

Performance with Motivation as an Intervening Variable. Proceedings of AICS-Social Sciences, 441-446.

Jufrizen, \& Rahmadhani, K. N. (2020). Pengaruh Budaya Organisasi Terhadap Kinerja Pegawai

Dengan Lingkungan Kerja Sebagai Variabel Moderasi. Jurnal Manajemen Dan Bisnis

Dewantara Vol., 3(1), 66-79.

Juliana, I., \& Manurung. (2014). Metodologi Penelitian Bisnis. UMSU Press.

Juliandi, A. (2015). Metodologi Penelitian Bisnis. UMSU PRESS.

Julita, J., \& Arianty, N. (2017). Pengaruh Komunikasi Dan Lingkungan Kerja Terhadap Kinerja

Karyawan Pada PT. Jasa Marga (Persero) TBK Cabang Belmera Medan. Prosiding Seminar Nasional Multidisiplin Ilmu Universitas Asahan 2018, 195-205.

Kadarisma. (2012). Manajemen Kompensasi. Raja Grafindo Persada.

Kadarisman, M. (2017). Manajemen Pengembangan Sumber Daya Manusia. Jakarta: Rajawali Pers.

Kasmir. (2015). Manajemen Sumber Daya Manusia. Rajawali Pers.

Kasmir. (2018). Analisis laporan keuangan. Rajawali Pers.

Manihuruk, C. P., \& Tirtayasa, S. (2020). Pengaruh Stres Kerja, Motivasi Kerja dan Lingkungan

KerjaTerhadap Semangat Kerja Pegawai. MANEGGGIO: Jurnal Ilmiah Magister Manajemen, 3(2), 296-307.

Marjaya, I., \& Pasaribu, F. (2019). Pengaruh Kepemimpinan, Motivasi, Dan Pelatihan Terhadap Kinerja Pegawai. Jurnal Ilmiah Magister Manajemen, 2(1), 129-147.

Murti, H., \& Srimulyani, V. A. (2015). Pengaruh Motivasi Terhadap Prestasi. Cendekia, 9(2), 135148.

Nitisemito, A. S. (2014). Manajemen Personalia. Ghalia Indonesia.

Prakoso, R. (2014). Pengaruh Lingkungan Kerja Terhadap Motivasi Kerja Dan Kinerja Karyawan (Studi Pada Karyawan PT. AXA Financial Indonesia Cabang Malang). Jurnal Administrasi Bisnis S1 Universitas Brawijaya, 14(2), 84429.

Prayogi, M. A., \& Nursidin, M. (2018). Pengaruh Pelatihan Dan Motivasi Kerja Terhadap Kinerja Karyawan.

Rezita, R. (2017). Pengaruh Lingkungan Kerja Terhadap Motivasi Kerja Karyawan di Bank Jatim Cabang Utama Surabaya. Jurnal Pendidikan Administrasi Perkantoran, 1-15.

Rizal, S. M., \& Radiman, R. (2019). Pengaruh Motivasi, Pengawasan, dan Kepemimpinan Terhadap Disiplin Kerja Pegawai. Jurnal Ilmiah Magister Manajemen, 2(1), 117-128. 


\section{Volumes 1 No 2 (2021)}

The Role of Work Motivation in Mediating the Effect of the Work Environment on Employee

Performance

DOI: 10.54443/ijebas.v1i2.75

Robbin, P. . (2015). Manajemen Sumber Daya Manusia. Rajawali Pers.

Rosmaini, \& Tanjung, H. (2019). Pengaruh Kompetensi, Motivasi Dan Kepuasan Kerja Terhadap Kinerja Pegawai. Jurnal Ilmiah Magister Manajemen, 2(1), 1-15.

Sari, F. P., \& Aziz, N. (2019). Pengaruh Lingkungan Kerja Terhadap Kinerja Yang Dimediasi Oleh Motivasi Kerja Karyawan Rocky Plaza Hotel Padang. 1-18. https://doi.org/10.31219/osf.io/m8pn3

Saydam, G. (2012). Manajemen Sumber Daya Manusia (Human Resource) Suatu pendekatan Mikro. Djanbatan.

Sedarmayanti. (2013). Manajemen Sumber Daya Manusia. Refika Aditama.

Sembiring, M., Jufrizen, J., \& Tanjung, H. (2021). Efek Mediasi Kepuasan Kerja pada Pengaruh Motivasi Dan Kemampuan Kerja Terhadap Kinerja Pegawai. Maneggio: Junal Ilmiah Magister Manajemen, 4(1), 130-143. https://doi.org/10.30596/maneggio.v4i1.6775

Setiawan, K. C. (2015). Pengaruh Motivasi Kerja Terhadap Kinerja Karyawan Level Pelaksana Di Divisi Operasi PT. Pusri Palembang. Psikis-Jurnal Psikologi Islami, 1(2), 43-53.

Siagian, T. S., \& Khair, H. (2018). Pengaruh Gaya Kepemimpinan Dan Lingkungan Kerja Terhadap Kinerja Karyawan Dengan Kepuasan Kerja Sebagai Variabel Intervening. Maneggio: Jurnal Ilmiah Magister Manajemen, 1(1), 59-70. https://doi.org/10.30596/maneggio.v1i1.2241

Soetopo, I., Kusmaningtyas, A., \& Andjarwati, T. (2019). Pengaruh Gaya Kepemimpinan Transformasional, Karakteristik Individu, Lingkungan Kerja Terhadap Motivasi Kerja Dan Kinerja Guru Smk Negeri 1 Tambelangan Sampang. JMM17: Jurnal Ilmu Ekonomi Dan Manajemen, 5(02). https://doi.org/10.30996/jmm.v5i02.1947

Sondang P. Siagian. (2014). Manajemen Sumber Daya Manusia. Bumi Aksara.

Subroto, setyowati. (2017). Analisis Pengaruh Locus Of Control dan Stres Kerja Terhadap Kinerja Karyawan Lembaga Pengembangan Jasas Kontruksi Provinsi Jawa Tengah. Jurnal Ilmiah Manajemen \& Bisnis, 18(2), 129-139.

Sudaryo. (2018). Manajemen Sumber Daya Manusia, Kompensasi Tidak Langsung dan Lingkungan Kerja Fisik. Yogyakarta: Gosyen Publishing.

Sugiyono. (2016). Statistika Untuk Penelitian. Alfabeta.

Surjosuseno. (2015). Pengaruh Lingkungan Kerja Dan Motivasi Kerja Terhadap Kinerja Karyawan Pada Bagian Produksi UD Pabrik Ada Plastic.

Surwanti, A. (2011). Motivasi Kerja, Kepuasan Kerja, Dan Kinerja. Jbti, 1(1), 86-95.

Tamali, H., \& Munasip, A. (2019). Pengaruh Kompensasi, Kepemimpinan, Dan Lingkungan Kerja Terhadap Kepuasan Kerja Karyawan. Jurnal Ilmiah Magister Manajemen, 2(1), 55-68.

Tobing, S. J., \& Napitupulu., A. H. (2011). Kiat Menjadi Supervisor Andal. Erlangga.

Wibowo. (2011). Manajemen Kinerja. Rajawali Pers.

Wibowo. (2014). Manajemen Kinerja Edisi keempat. Penerbit PT. Raja Grapindo Persada.

Wibowo. (2016). Manajemen Kinerja. PT.Rajagrafindo Persada. 